\title{
CYP1A1 Gene
}

National Cancer Institute

\section{Source}

National Cancer Institute. CYP1A1 Gene. NCI Thesaurus. Code C18498.

This gene plays a role in the oxidation of procarcinogens. This process activates these compounds to carcinogens. 